\title{
Studies in the Ericoideae (Ericaceae). VIII. New species in Erica, section Pseuderemia, from southern Africa
}

\author{
E.G.H. OLIVER* and INGE M. OLIVER*
}

Keywords: Erica, new species, southern Africa, taxonomy

\author{
ABSTRACT
}

Three new species are described in the genus Erica L.: E. abbottii E.G.H. Oliver, endemic to the South Coast of Natal and neighbouring Transkei. E. swaziensis E.G.H. Oliver, a Swaziland endemic, and $E$. ingeana E.G.H. Oliver which is confined to the high mountains in the eastern Little Karoo of the Cape Province.

\section{UITTREKSEL}

Drie nuwe spesies in die genus Erica L. word beskryf: $E$. abbottii E.G.H. Oliver. endemies tot die Suidkus van Natal en aangrensende Transkei, $E$. swaziensis E.G.H. Oliver, endemies tot Swaziland, en $E$ ingeana E.G.H. Oliver met 'n beperkte verspreiding op die hoë berge in die oostelike Klein Karoo van die Kaapprovinsie.

\section{INTRODUCTION}

Studies in Section Pseuderemia of the genus Erica L. prompted by the recent discovery of a new species from the Natal South Coast, have brought to light several distinct new species, which had hitherto remained undescribed. This research also revealed problems in a number of species complexes as well as in the delimitation of the section and its position in the genus.

Section Pseuderemia was created by Bentham (1839) and upheld by Guthrie \& Bolus in their treatment of the genus for Flora capensis (1905). In it were placed those species with small, corolline flowers aggregated into head-like inflorescences placed at the ends of main branches and lateral branchlets, the flowers having the stamens included. The delimitation of sections within the genus Erica has up to now provided a reasonably useful framework for the identification of species, but has also led to many problems due to the artificiality of the sections. In the case of Section Pseuderemia there are indications that species placed in several other sections, such as Sections Ceramia. Ephebus, Pachysa, Orophanes and even Section Dasyanthes with its long-tubed flowers, could have a closer relationship to species in Section Pseuderemia than to species in their own sections. This problem can only be dealt with satisfactorily after an assessment of the whole genus at subgeneric level. The three new species are therefore described below within the section as currently construed

The section contains some 18 species including the three new species described below and is distributed widely throughout the southern half of the African continent. Among the earlier described species, E. johnstoniana Britten is found in Malawi. Mozambique and Zimbabwe. $E$. holtii Schweick. in the eastern Transvaal, E. reenensis Zahlbr. in the Natal Drakensberg. and the complex of E. cooperi $\mathrm{H}$. Bol./E. baurii $\mathrm{H}$. Bol. in Natal and the Transkei at lower altitudes. The remaining eight species

\footnotetext{
* Stellenbosch Herbarium, National Botanical Institute. P.() Box 471. Stellenbosch $76(x)$

MS received: $1491-(14-10$
}

occur in the south-western Cape Province. E. solandra Andr. is confined to the Outeniqua Mountains. The complex of $E$. sphaerocephala Wendl. ex Benth./E. maderi Guth. \& Bol./E. oxysepala Guth. \& Bol. is common in the Ceres to Clanwilliam Districts and exhibits much variation over both geographical as well as altitudinal ranges. $E$. cermua C.V. Montin and $E$. pudens H.A. Baker are both western Cape species found from Ceres northwards as far as Namaqualand ( $E$. pudens). The other four species are very localized: E. clavisepala Guth. \& Bol. in the southern Cape Peninsula; $E$. acockii Compton, known only from near Bellville and now extinct: $E$. orculiflora Dulfer from the mountains just south of Ceres; and the very distinct E. grevii Guth. \& Bol., recorded only as a single collection from an unspecified locality in the Cold Bokkeveld in 1860 .

Erica abbottii E.G.H. Oliver, sp. nov., in sectione Pseuderemia. habitu laxo prostrato, corolla alba, antheris luteolis, ovario pilis stellatis tecto, ovulis 4 ad 6 in quoque loculo dignoscenda.

Fruticulus sparsus debilis effusus ad $600 \mathrm{~mm}$ diametro, pubescens et pilis dispersis longis glandulosis tectus, glandibus rubentibus. Rami tenues filo metallico similes. Folia 4-nata patentia, $2.5 \mathrm{~mm}$ longa, oblonga, acuta. Flores 4-9 in capitis ad extrema ramorum ramulorumque. pedicello $1,0-2.5 \mathrm{~mm}$ longo; bractea mediana usque subapproximata, foliacea, $2.5-3.5 \mathrm{~mm}$ longa linearilanceolata; bracteolis 2 approximatis, subfoliaceis, linearilanceolata. Calyx 4-partitus, 2.5-3,8 mm longus, anguste oblongus. Corolla 4-lobata, 3-5 mm longa, obovoideourceolata vel obconica, pubescens, alba, lobis erectis papillatis. Stamina 8, libera inclusa: filamentis linearibus. apice sigmoideis, glabris; antheris subbasalibus, 0,8-1,3 $\mathrm{mm}$ longis, glabris, luteolis, aristatis, aristis theca dimidio brevioribus, poro theca dimidio breviore, polline in tetradis. Orarium 4-loculare, ovulis 4-6 in quoque loculo, $0.8-1.0 \mathrm{~mm}$ longum subcylindraceum, hispidum pilis stellatis; stylo $2.0-2.2 \mathrm{~mm}$ longo glabro; stigmate simplici. incluso. Fructus capsularis, septa ad basim libera. seminibus subsphaeroideis $0.6 \mathrm{~mm}$ diametro, reticulatis cellulis parvis multis. Figura 1 . 


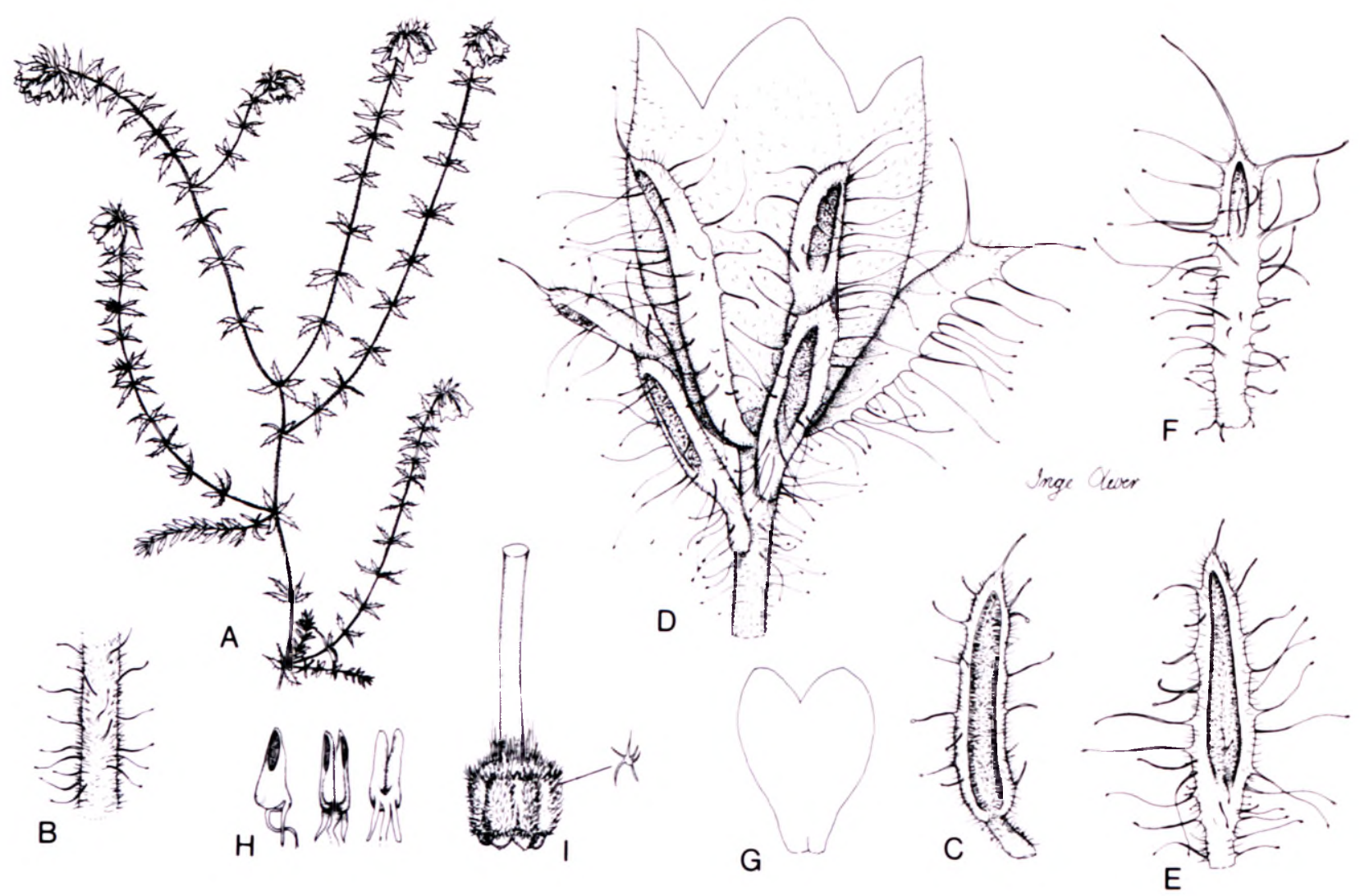

FIGURE 1. - Erica abbottii: A, flowering branch, $\times 2$; B. branch; C, leaf; D, flower; E, bract; F, sepal; G, outline of corolla, $\times 12 ;$ H, anther. side, front and back views; I, gynoecium, with a stellate hair inset $(\times 50)$. B-F. H \& I. $\times 25$. All drawn from the type, Abbott 2273 (STE).

TYPE. - 3030 (Port Shepstone): Natal, Port Edward area, Umtamvuna Nature Reserve, Cascades, 18 December 1984, (-CC), Abbott 2273 (PRE, holo.; NH, PRU, STE).

Shrublet sparse, weak, sprawling to $600 \mathrm{~mm}$ diam., pubescent all over and with scattered long gland-tipped hairs, the glands red. Branches thin and wiry with no infrafoliar ridges, internodes up to $10 \mathrm{~mm}$ long. Leaves 4-nate spreading, 2,5-3,0 mm long, oblong, acute, with a long apical hair, subopen-backed below; petiole $0.5 \mathrm{~mm}$ long, pubescent. Flowers 4-9 in heads at ends of main and lateral branches; pedicel 1,0-2,5 mm long, half the length of the corolla or shorter; bract median to subapproximate, foliaceous, 2,5-3,5 $\mathrm{mm}$ long, linearlanceolate; bracteoles 2, approximate, subfoliaceous, only terminally sulcate, $2,5-3,5 \mathrm{~mm}$ long, linear-lanceolate. Calyx 4-partite, 2,5-3,8 mm long, half as long as to just longer than the corolla, narrowly oblong. Corolla 4-lobed, 3-5 mm long, obovoid-urceolate or obconical, white, lobes erect, broadly rounded, papillate, not hairy. Stamens 8. free. included, half the length of the corolla; filaments linear, apically sigmoid. glabrous; anthers sub-basally attached, 0,8-1,3 mm long. glabrous, pale yellow, pore half the length of the theca, aristate. the awns simple. pointing downwards and half the length of the theca: pollen in tetrads. Ovary 4-locular with 4-6 ovules per locule, $0,8-1,0 \mathrm{~mm}$ long, subcylindric and obtuse, hispid with stellate hairs; style $2,0-2,2 \mathrm{~mm}$ long. glabrous; stigma simple, included. Fruit a dehiscent capsule with septa free to the base; seeds relatively large subsphaeroid. $0.6 \mathrm{~mm}$ in diam., reticulate with numerous small cells. Figure 1.
Erica abbottii was recently collected by A. Abbott, a farmer in the Port Edward area, who is keenly interested in natural history and conservation. He is involved in a detailed survey of the species in the nearby Umtamvuna Nature Reserve and in the process has made some very interesting records, including several new species. When trying to identify this material we found that a more detailed study of the species in Section Pseuderemia was required in order to establish the taxonomic status of his collection and also its affinities. In this regard we are most grateful to him for his fine collections and his notes and photographs of $E$. abbottii.

The species is the only truly prostrate one in this section and as such is unique among those species occurring in the summer rainfall area of southern Africa. It forms prostrate, lax plants with long branches straggling among the low grasses in moist seepage areas or alongside streams. This character and the white corolla, pale yellow anthers, stellate hairs on the ovary and 4-6 ovules per locule serve to characterize $E$. abbottii.

The lax habit is not so well developed in E. swaziensis which has bright pink, very differently shaped flowers. It approaches $E$. holtii from the Drakensberg and eastern Transvaal in which the flowers are also white, but that species forms low compact many-stemmed shrublets in which the corolla is globose-urceolate with spreading lobes and 10-18 ovules per locule. The single collection of the latter species from the high Drakensberg of Natal. Esterhuysen 20234, is anomalous. The occurrence of stellate hairs on the ovary in $E$. abbottii is most unusual in the genus, but is shared with the $E$. cooperi/baurii complex 
which occurs further inland in the Transkei northwards to central Natal. However, this complex forms stout, woody, erect shrubs with stiff, dendroid hairs all over the plants and there are on average 20 ovules per locule.

E. abbotrii is one of six species of Erica known to occur in the coastal areas of southern Natal and northern Transkei (Figure 2), the others being $E$. aspalathifolia $\mathrm{H}$. Bol., $E$. caffra L., E. cerinthoides L., E. cubica L. and $E$. natalitia $\mathrm{H}$. Bol. The new species is, however, the only one endemic to the area and as such is one of several endemic species in genera with their main distribution in the Cape Floral Region. Examples of this situation are clearly shown by Leucospermum innovians Rourke and Leucadendron pondoense Van Wyk, both in the Proteaceae, and Raspalia trigyna (Schltr.) Duemmer in the Bruniaceae. The phytogeography and endemism of this area is discussed fully by Van Wyk (1990a \& b).

NATAL. -3030 (Port Shepstone): Umtamvuna Nature Reserve Cascades, 8-1-1984, (-CC), Abbott 1610 (NH. PRE): ibid.. 18-12-84. Abbott 2273 (NH. PRE, PRU, STE); Mpunzaana River just S of Umtamvuna/Hlolweni junction, $200 \mathrm{~m}, 24-1-86$. (-AA). Van Wyk 7249 (PRE)

TRANSKEI - 3129 (Port Si Johns): Mkambati Game Reserve. Daza River. 13-12-86. (-BD), Jordaan 1055 (K. MO. NH. PRE. STE). 3130 (Port Edward): Mzamba. Mzamba/Nilakwe Rivers, $300 \mathrm{~m}, 29-10-87$. (-AA), Abboll 404I (PRU, STE).

Erica swaziensis E.G.H. Oliver, sp. nov., in sectione Pseuderemia, distincta propter habitum laxum, internodos ramulorum florentium longos, flores roseos, pilos floribus typorum trium-eos multos breviores, eos intermediores glandulosos, eos longos simplices vel furcatos - aristas antherarum decurrentes.

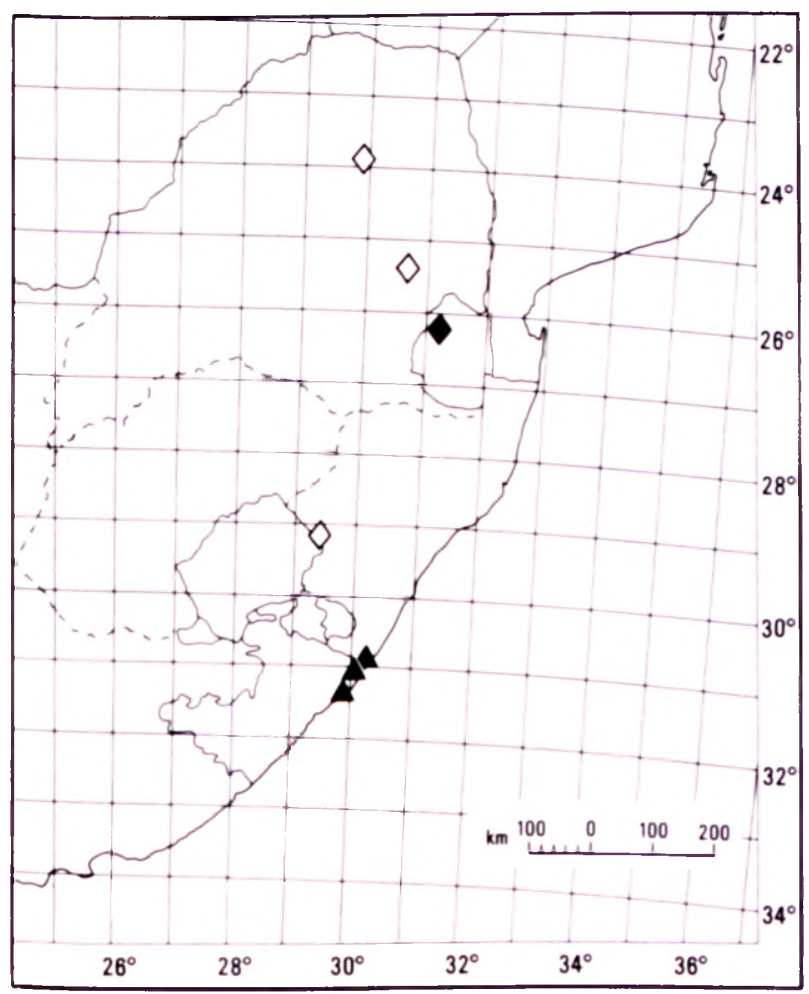

FIGURF 2, - The known distribution of Erica abborti. $\Delta$ : $E$ swaziensis $\checkmark$ : and $E$ holtii, $\diamond$.
Fruticulus laxus ad $400 \mathrm{~mm}$ altus vel effusus. Rami filo metallico similes, internodis ramulorum florentium ad 60 $\mathrm{mm}$ longis, pilosi pilis longis glandulosis glandibus albis. Folia 4-nata, suberecta. subimbricata. $2,0-2,5 \mathrm{~mm}$ longa, anguste ovata, in toto pilosa, ciliata pilis longis glandulosis. Flores 12 in capitis in extremis ramorum ramulorumque, pedicello $2 \mathrm{~mm}$ longo, pubescenti et pilis longis glandulosis; bractea subapproximata, $2 \mathrm{~mm}$ longa, lanceolata, pubescenti et pilis dispersis longioribus et etiam longioribus simplicibus furcatis; bracteolis 2 bractea similibus. Calyx 4-partitus, oblongus ad lanceolatus acutus, 1,7-2,0 mm longus, tubo corollae dimidio brevior, pubescente ut in bractea. Corolla 4-lobata rosea, tubo anguste ovoideo, $3 \mathrm{~mm}$ longo, glabro, lobis erectis ad subpatentibus, late ellipticis, $0.8 \mathrm{~mm}$ longis, papillatis papillatocrenulatis. Stamina 8, libera, inclusa, longitudine $3 / 4$ tubum corollae aequantia: filamentis linearibus, apice parum curvatis; antheris $0.6 \mathrm{~mm}$ longis, sub-basalibus, glabris, bubalinis, aristatis, aristis porum aequantibus, parum decurrentibus, serratis, poro longitudine $2_{3}$ thecae partes aequanti, polline in tetradis. Ovarium 4-loculare ovulis 15 in quoque loculo, $1 \mathrm{~mm}$ longum, late obovoideum. hispidulum; stylo $1.5 \mathrm{~mm}$ longo glabro; stigma simplici, incluso. Fructus capsularis, septa ad basim libera. seminibus ovoideis, luteolis, reticulatis cellulis multis parvis. Figura 3.

TYPE. - 2631 (Mbabane): Swaziland, Mbuluzi Falls, 9 April 1955, (-AA), Compton 25085 (NBG, holo.: K. PRE).

Shrublet loose and straggling, $200-400 \mathrm{~mm}$ tall or spreading. Branches thin and wiry with slight infrafoliar ridges, internodes $10 \mathrm{~mm}$ long or less, up to $60 \mathrm{~mm}$ on flowering branches, pilose and with scattered long glandtipped hairs, the glands white in young stages. Leaves 4-nate suberect and subimbricate, $2.0-2.5 \mathrm{~mm}$ long. narrowly ovate, pubescent all over. ciliate with long glandtipped hairs: petiole very short, $0.2 \mathrm{~mm}$ long, pubescent. Flowers in heads of 12 at ends of main and lateral branches: pedicel $2 \mathrm{~mm}$ long. dark red, pubescent and with scattered long gland-tipped hairs; bract subapproximate. $2 \mathrm{~mm}$ long. lanceolate, pubescent and with a few scattered somewhat longer gland-tipped hairs and longer simple or fork-tipped hairs, red at base, sulcate and green in upper threequarters; bracteoles 2. like the bract. Calyx 4-partite, oblong or lanceolate, acute, 1.7-2,0 mm long, half as long as the corolla, pubescent and with slightly longer scattered gland-tipped hairs, ciliate with long simple and fork-tipped hairs, red with apical green sulcate portion. Corolla 4-lobed, bright pink, tube narrowly ovoid, $3 \mathrm{~mm}$ long. glabrous, lobes erect to spreading, broadly elliptic, $0.8 \mathrm{~mm}$ long. papillate outside and inside, papillate-crenulate. Stamens 8 , free, included, about three-quarters the length of the corolla tube: filaments linear, slightly curved at apex: anthers $0.6 \mathrm{~mm}$ long, sub-basally attached, glabrous. light brown, aristate, awns as long as the pore, slightly joined to the filament, with serrated edges, pore two thirds the length of the theca: pollen in tetrads. Ovary 4-locular with 15 ovules per locule. $1 \mathrm{~mm}$ long. broadly obovoid 8 -lobed. covered with short stiff hairs; style $1.5 \mathrm{~mm}$ long. just shorter than corolla tube, glabrous: stigma simple. Fruit a dehiscent capsule with septa free to the base: seeds ovoid, pale yellow. with numerous small reticulate cells Figure 3. 


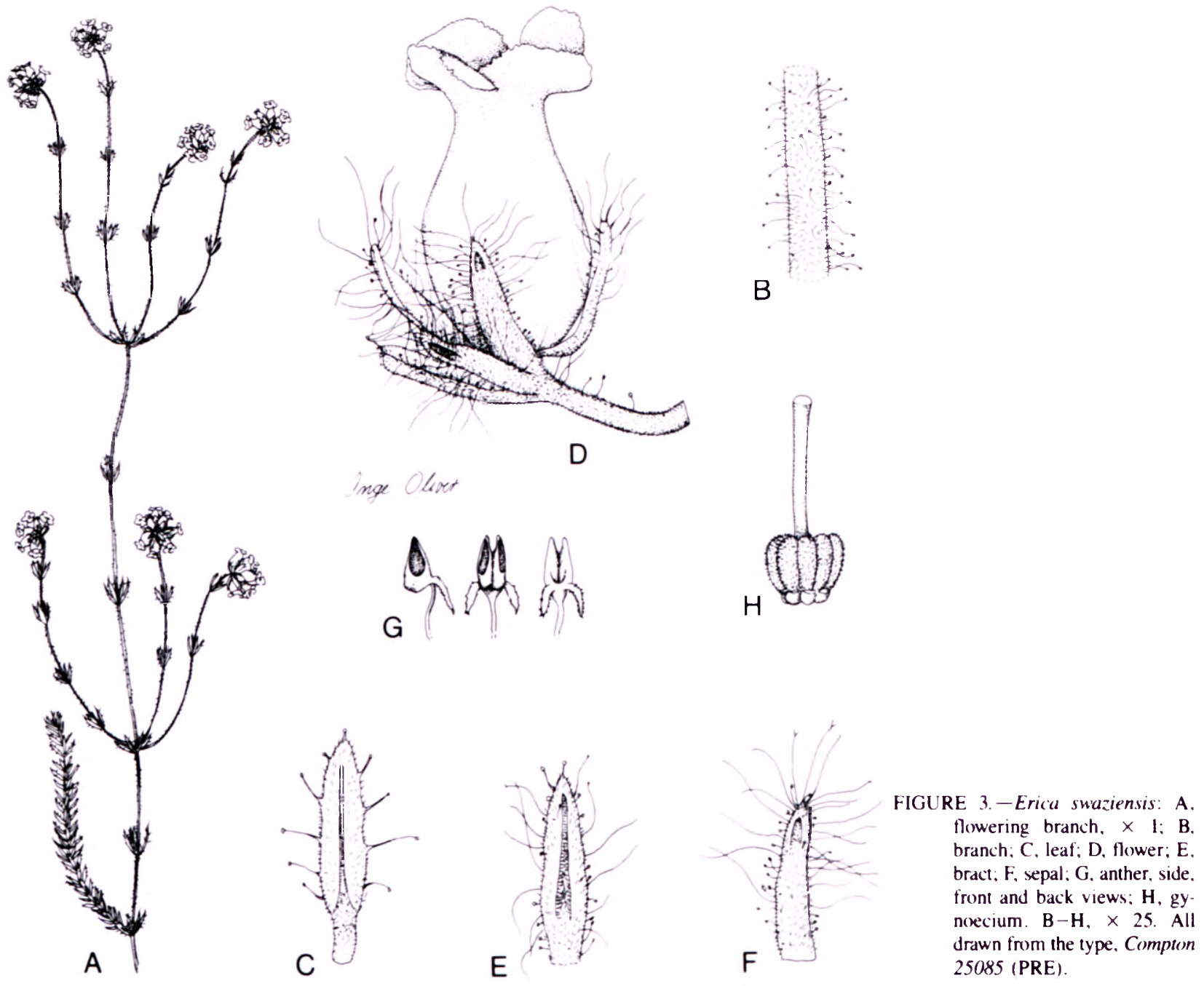

This species is distinguished by its lax habit, the long internodes of the flowering branches, glabrous pink corolla with large spreading lobes, partly decurrent anthers and by the lack of glands on the longest hairs, but white glands on the medium-length hairs.

It is allied to the group of species described here in a number of characters. It differs from the rather lax, pinkflowered $E$. ingeana, which also has spreading corolla lobes, by the lobes being much wider than long and by the glabrous corolla, white glands on the medium-length hairs and the lack of glands on the long hairs.

E. swaziensis was listed by Compton (1976) as E. holtii which has an anomalous distribution from the type locality near Lydenburg on the eastern Transvaal escarpment to the high Drakensberg of Natal, from where it has been collected only once, Esterhuysen 20234, in 1952. The distribution of $E$. holtii has recently been extended further north to the Wolkberg, Venter 10859a. It is, however, a species with white, pubescent flowers of ovoid-urceolate shape with very small broadly rounded corolla lobes on plants which are multi-stemmed from a very woody base, the main branches being rather short.

Verdoorn (1954), when discussing the species of Erica from the Transvaal, mentioned the occurrence of $E$. holtii in Swaziland, presumably based on the old Nicholson collection in PRE. She noted, however, that the Swaziland material possessed longer and more urceolate flowers than the type.
The name of this species is appropriate because it is the only species of Erica confined to Swaziland. The other seven species are more widespread with $E$. cerinthoides occurring as far south as the Cape Peninsula and $E$. woodii from the southern Drakensberg to eastern Zimbabwe. $E$. swaziensis appears to be very localized in its distribution. being confined to the mountains just north and north-east of Mbabane. The habitat is not recorded on any of the collections, but Compton (1976) notes the habitat as 'sheltered grassy places'.

SWAZILAND - 2631 (Mbabane): Mbuluzi Falls. 9-4-1955. (-AA) Compton 25085 (NBG, K. PRE); Miller's Falls, $1370 \mathrm{~m}$, 6-4-1956 (-AA/AC), Compton 25854 (NBG); Black Umbuluzi Valley. $1300 \mathrm{~m}$ 24-2-1978. (-AA/AC), Kemp 130I (PRE); near Mbabane. 5-1939. (-AA/AC), B Nicholson in PRE SI2I7 (PRE).

Erica ingeana E.G.H. Oliver. sp. nov., in sectione Pseuderemia distincta propter lobos corollae roseae magnos longiores quam latiores, folia ovata, pilos longos molles omnes glandibus terminatos.

Fruticulus laxus decumbens usque erectus ad $300 \mathrm{~mm}$ altus. Rami filo metallico similes, pilosi et pilis dispersis longis glandulosis, glandibus atrorubentibus, internodis ad $20 \mathrm{~mm}$ longis. Folia 4 -nata suberecta ad parum patentia. $2.0-2,5 \mathrm{~mm}$ longa petiolo $0.4 \mathrm{~mm}$ longo, ovata, sparse pilosa ciliata pilis longis glandulosis. Flores $12(16)$ in capitis in extremis ramorum ramulorumque; pedicello 2 $\mathrm{mm}$ longo; bractea remota ad mediana, $2 \mathrm{~mm}$ longa, ovata. pubescens et pilis dispersis longioribus glandulosis et 
pilis etiam longioribus simplicibus vel furcatis; bracteolis 2 bractea similibus. Calyx 4-partitus, $1,7 \mathrm{~mm}$ longus, tubo corollae dimidio brevior, anguste oblongus, pilis ut in bractea bracteolisque. Corolla 4-lobata, rosea, tubo $3 \mathrm{~mm}$ longo, anguste ovoideo, sparse piloso, lobis 1,0-1,3 mm longis, ellipticis, erectis ad patentibus, papillatis papillatocrenulatis. Stamina 8, libera, inclusa; filamentis linearibus apice sigmoideis; antheris $0.6 \mathrm{~mm}$ longis, sub-basalibus, glabris, poro longitudine ${ }^{2 / 3}$ thecae partes aequanti, aristatis, bubalinis, polline in tetradis. Ovarium 4-loculare ovulis 14 in quoque loculo, $9 \mathrm{~mm}$ longum, subcylindraceum, obtusum, pubescens apice hispidum; stylo 2,0-2,5 mm longo glabro; stigma simplici, manifesta. Fructus capsularis, septa ad basim libera, seminibus ovoideis reticulatis cellulis multis parvis. Figura 4.

TYPE. - 3322 (Oudtshoorn): Swartberg, NE of Blesberg at head of Oorlogskloof, $1647 \mathrm{~m}, 7$ January 1975 , (-BC), I. Oliver sub E.G.H. Oliver 5656 (STE, holo.; BM, BOL, K, MEL, MO, P, PRE, S, W).

Shrublet straggling, single-stemmed, decumbent to erect and compact, up to $300 \mathrm{~mm}$ tall. Branches $200-400 \mathrm{~mm}$ long, wiry, pilose and with scattered long gland-tipped hairs, glands dark red, internodes up to $20 \mathrm{~mm}$ long on flowering branches, with no infrafoliar ridges. Leaves 4-nate, suberect to slightly spreading, $2,0-2,5 \mathrm{~mm}$ long with petiole $0.4 \mathrm{~mm}$ long, ovate, sparsely pilose all over and ciliate with long gland-tipped hairs. Flowers in heads of $12(16)$ at the ends of main and lateral branches; pedicel $2 \mathrm{~mm}$ long, pubescent and with long gland-tipped hairs, glands dark red; bract remote to median, $2 \mathrm{~mm}$ long, ovate, pubescent and with somewhat longer gland-tipped hairs and even longer simple or forked hairs, red at base with green sulcate upper half: bracteoles like bract, $2 \mathrm{~mm}$ long. Calyx 4-partite, segments about $1.7 \mathrm{~mm}$ long. half the length of the corolla tube, leaflike, narrowly oblong. pubescent and with somewhat longer gland-tipped hairs and even longer simple or fork-tipped hairs mostly confined to margins. Corolla 4-lobed, pink, tube $3 \mathrm{~mm}$ long, narrowly ovoid, sparsely pilose, lobes $1.0-1.3 \mathrm{~mm}$ long, elliptic, obtuse, erect to spreading, papillate abaxially, papillate-crenulate. Stamens 8 , free, included; filaments linear apically sigmoid, half the length of the corolla tube; anthers $0,6 \mathrm{~mm}$ long, sub-basally attached, thecae rectangular, glabrous, pore $2 / 3$ length of theca, aristate, light brown, awns as long as the pore; pollen in tetrads. Ovary 4-locular with 14 ovules per locule, $9 \mathrm{~mm}$ long, subcylindric with obtuse to flattened apex and 8 external lobes, pubescent, apically hispid; style 2,0-2,5 mm long. glabrous; stigma simple, manifest. Fruit a dehiscent capsule with septa free to the base; seeds ovoid, reticulate with numerous small cells, yellow. Figure 4.

This species is distinguished among the small-flowered species of this section by its relatively long spreading corolla lobes which are longer than broad and are reminiscent of those in some species of Section Euryloma. It is most closely related to $E$. solandra which forms a stouter, erect shrub with numerous rigid, coarse hairs which are eglandular. $E$. solandra also has much larger leaves and dendroid teeth to the corolla lobes. $E$. ingeana resembles the new species, $E$. swaziensis above, in its large corolla lobes, but in that species the lobes are much broader than long and the corolla is glabrous.

Erica ingeana has been known from a number of collections since the first was made by Miss E.E. Esterhuysen in 1941. We were first introduced to this species through a collection made by one of us (I.M. Oliver) on a joint expedition to the Blesberg in 1975. The species occurs in moist seepage areas, which may be only seasonally wet, on the northern slopes of the eastern end of the Swartberg and also on the Anthoniesberg and the Kouga Mountains further east (Figure 5). E. solandra is confined to the slopes of a small section of the Outeniqua Mountains north and north-east of George where it grows in drier places which, however, receive a fairly high amount of rain.

CAPE - 3322 (Oudtshoorn): Swartberg. NE of Blesberg, head of Oorlogskloof. 1647 m. 7-1-1975. (-BC). Oliver 5656 (BM. BOL. K. MEL. MO. P. PRE. S. STE. W): Blesberg. top of Tierkloof. $1830 \mathrm{~m}$.
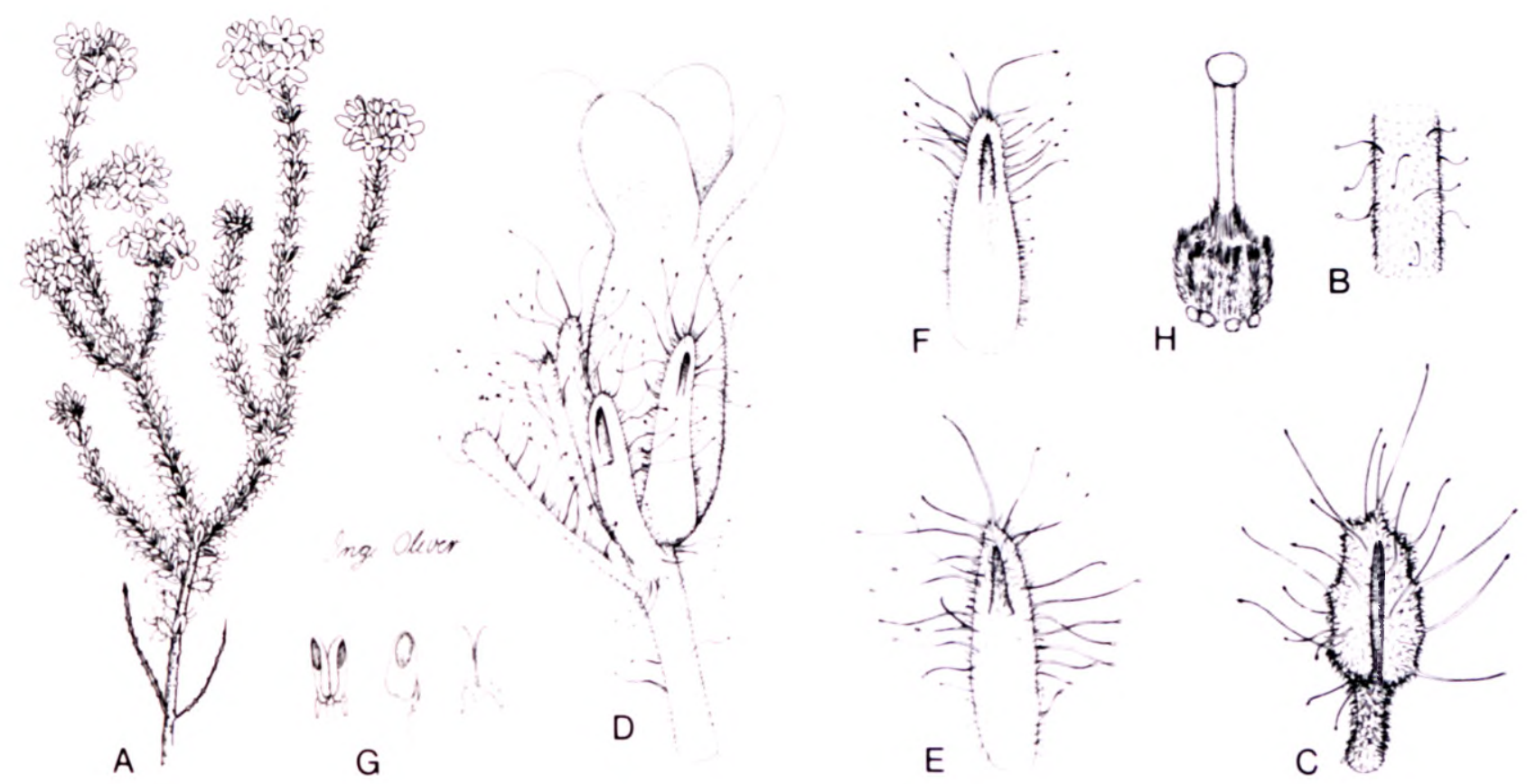

FIGURE 4 - Erica ingeana: A. thowering branch. $\times$ 1, B. hranch, C. leaf, D. flower: E. hract: F, sepal, G, dnther. front. side and hack vieu:s: H. gynocium. B-H. $\times 25$ All dratun from the Iype. Oliver 5656 (STE). 


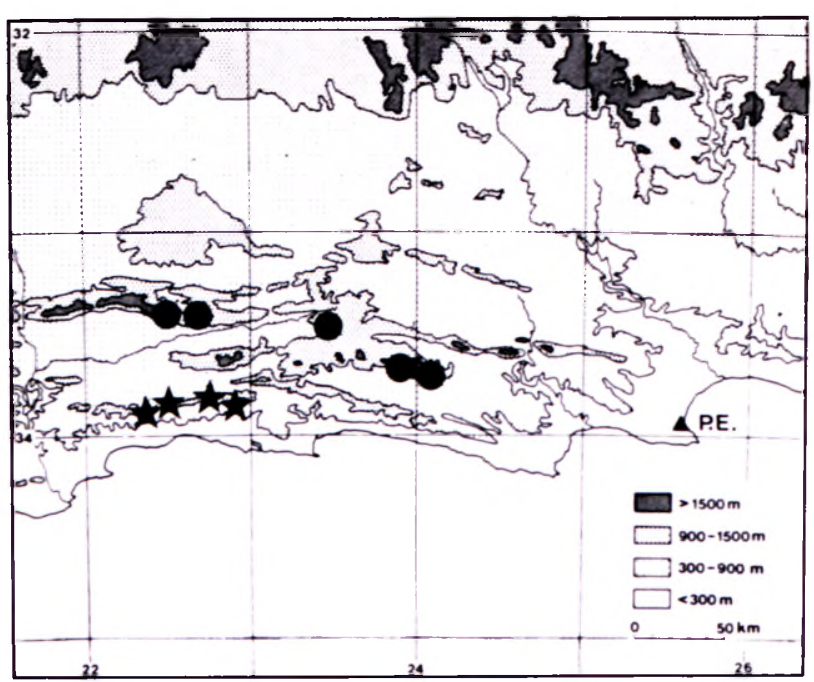

FIGURE 5.-The known distribution of Erica ingeana. : and $E$. solandra,

12-1-1981, Vlok 102 (STE); ibid., 1647 m, 4-2-1984, Vlok 810 (STE); ibid., $1660 \mathrm{~m}, 15-12-1986,(-\mathrm{BC})$. Schumann 495 (STE); N base of Bloupunt at $\mathrm{N}$ entrance to Meiringspoor, $790 \mathrm{~m}, 15-7-1990$. (-BC). Vlok
2330 (STE). 3323 (Willowmore): Anthoniesberg S slopes, $1500 \mathrm{~m}$. 19-10-1955. (-AD). Esterhuysen 24952 (BOL); Kouga Mtns, peak E of Smutsberg, 27-11-1941, (-DB), Esterhuysen 7033 (BOL); foothills near Smutsberg. $900 \mathrm{~m}, 12-11-1944$. (-DB), Esterhuisen BOL 52462 (BOL). 3324 (Steytlerville): Kouga Mins, foothills near Kouga Peak. $1200 \mathrm{~m}$. 14-11-1944. (-CA), Esterhuysen 10835 (BOL).

\section{REFERENCES}

BENThaM. G. 1839. Ericaceae. In A.P. De Candolle. Prodromus systematis naturalis regni vegetabilis 7: 580-733. Paris.

COMPTON. R.H. 1976. Flora of Swaziland. Journal of South African Botany Suppl. Vol. II.

GUTHRIE. F. \& BOLUS. H. 1905. Erica. In W.T. Thistleton-Dyer, Flora capensis 4.1: 4-315. Reeve. London.

VAN WYK, A.E. 1990a. A new species of Leucadendron (Proteaceae) from Pondoland, with a discussion of its biogeography. South African Journal of Botany 56: 458-466.

VAN WYK, A.E. 1990b. The sandstone regions of Natal and Pondoland: remarkable centres of endemism. In K. Heine. Palaeoecology of Africa Vol. 21. Balkema. Rotterdam.

VERDOORN. I.C. 1954. The Transvaal Ericaceae. Journal of South African Botany 20: 91-115. 


\title{
Cyanophyceae associated with mangrove trees at Inhaca Island, Mozambique
}

\author{
S.M.F. SILVA*
}

Keywords: Bostrychietum. Cyanophyceae, epiphytes. Inhaca Island, mangrove. taxonomy

\author{
ABSTRACT
}

A survey of the Cyanophyceae associated with two of the five mangrove trees and their associated Bostrychieta at Inhaca Island. Mozambique, was undertaken. Sixteen taxa belonging to 12 genera were identified. Of these. six taxa were new records for Mozambique, three at generic and three at specific level. Thirteen taxa of Cyanophyceae were found growing on Avicennia marina (Forssk.) Vierh. and four on Ceriops tagal (Perr.) C. B. Robinson. Chamaecalyx leibleiniae (H. Reinsch) Komarek \& Anagnostidis was the only Cyanophyceae to occur on both species of tree

\section{UITTREKSEL}

'n Opname van Cyanophyceae wat geassosieer word met twee van die vyf manglietbome en hul geassosieerde Bostrychieta op Inhaca Eiland. Mosambiek, is gedoen. Sestien taksons wat aan 12 genera behoort. is geidentifiseer. Ses van hierdie taksons was nuwe rekords vir Mosambiek, drie op genusvlak en drie op spesievlak. Daar is gevind dat dertien Cyanophyceae-taksons op Avicennia marina (Forssk.) Vierh. groei en vier op Ceriops tagal (Perr.) C. B. Robinson. Chamaecalyx leibleiniae (H. Reinsch) Komarek \& Anagnostidis was die enigste Cyanophyceae wat op albei boomspesies voorgekom het.

\section{INTRODUCTION}

After a long period of neglect. some attention has recently been given to epiphytic Cyanophyceae associated with mangroves with respect to their abundance and importance within this particular habitat (Berjak et al. 1977; Dor 1984; Lambert et al. 1989).

The Cyanophyceae from southern African mangroves were studied in detail by Lambert et al. (1989). This report constitutes an important contribution to our knowledge of the ecology and taxonomy of the Cyanophyceae in that region. The northern limit of sampling by Lambert $e t$ al. (1989) was in the Kosi Estuary which borders Mozambique (Figure lB). Inhaca Island is situated $\pm 180 \mathrm{~km}$ to the north. on the east coast of southern Africa, within the Indo-WestPacific biogeographic zone of the degree squares 2532DD and 2632BB (see Edwards \& Leistner 1971) (Figure 1A, B). It is of interest because of the well-zoned mangrove swamps, a feature not apparent in the swamps to the south (Berjak et al. 1977). The island is situated in the south of Mozambique, forming part of the barrier between the Indian Ocean and Maputo Bay (Figure 1). The largest stands of mangroves are located at the head of the northern and the southern bays (Figure IC) (Macnae \& Kalk 1969).

The mangrove vegetation on Inhaca Island is mainly composed of the following: Avicennia marina (Forssk.) Vierh. , Bruguiera gymnorrhiza (L.) Lam., Ceriops tagal (Perr.) C.B. Robinson, Lumnitzera racemosa Willd. and Rhizophora mucronata Lam. Ceriops tagal occupies the central areas of all mangrove swamps on the island and macroscopic growth of algae on its trunks is generally very scarce. Avicennia marina is a dominant member of the mangrove community. The pneumatophores very often

\footnotetext{
* Department of Botany. University of the Witwatersrand. Private Bag 3. WITS 2050, Johanneshurg

MS received 1991-05-(03.
}

possess a covering of several species of Rhodophyceae which are collectively known as 'Bostrychietum', which is defined thus by the predominance of species such as Bostrychia spp., Catenella spp., Caloglossa sp. and Murrayella sp. (Post 1936; Macnae \& Kalk 1962).

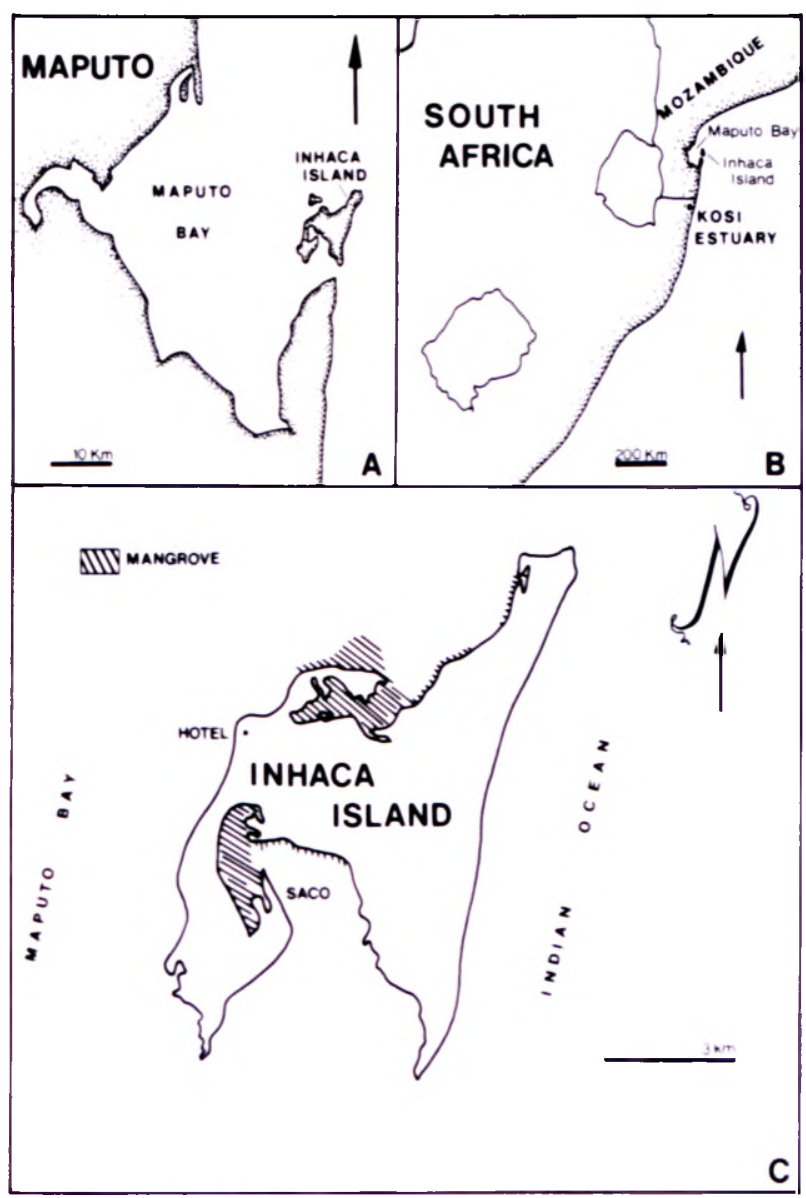

FIGURE 1.-Localization of the study site. 